\title{
Connections of Urban People on Indah Hanaco
}

\author{
Resti Nurfaidah \\ Balai Bahasa Jawa Barat \\ Bandung, Indonesia \\ sineneng1973@gmail.com
}

\begin{abstract}
Urban living was fast growing with its developed complexities that always accompanied the people lives in the urban area. Urban displayed many things that were growing so fast, practical, restricted, individualistic, and all-bossial. Those high complexities in urban areas had tremendous impacts on people connectivity in the area. Urban complexities had long been an interesting topic or source of idea for many writers on their works, among of them, Indah Hanaco. Hanaco, in each of her works, fully displayed portraits of families or urban people who had almost been untouched by traditional values. However, Hanaco seemed to remind the reader that we, the citizens of Indonesia, could not stand on the urban value alone. If so, we would lose our roots as Indonesian citizens. Urban people, with their urban values, had to be accompanied by traditional values. Thus, they will be able to stand firmly as an Indonesian citizen who had long been known to have a wealth of traditional value. This article was made through literature review on some of Hanaco's novels. The research was a qualitative and comparative descriptive analysis, with approaches on the concept of cultural studies, among others, cyberspace, gender, psychology, and connectivity. The hypothesis found in the data, among others, (1) urban people could not stand alone, but they always needed good connectivity with each other, especially when getting into trouble; (2) urban people could not solve their own problems and they tended to take the issue as an heirloom in life; (3) urban people tended to have complex traumatic backgrounds; (4) urban people tended to be self-defeating and self-interest; and (5) urban people could not stand alone with complete urban values, but still required traditional values which was derived from their ancestors.
\end{abstract}

\section{Keywords-human; urban; Hanaco; traditional values}

\section{INTRODUCTION}

From the beginning on earth, human was forced to face series of changes. Begun with little change, then it became bigger [1]. Changes occurred not only those things that are in his body, but inside his body, as well as outside himself. The change of nature, from day to night required a lot of adjustments. Various things, including infrastructures, must be owned to survive, including when he faced many problems. Human life developed fast and moved faster and thus leaves a wide range of impressions and impacts behind the change. The limitation of human life in two distinct areas, urban and rural, shows a very prominent rate of development of life. The urban people life is never separated from rural life. Urban is mostly populated by migrants from various regions, especially rural. Urban people come with all the traditional values. Meetings and human connections in urban areas gradually change the integrity of traditional values and bring new values. Not surprisingly, in some circles, these values are still believed. There is also half-acting, reluctant to deprive traditional values, but unable to resist new values. Others are also those who cannot maintain the traditional values at all and only embrace the new values completely.

The fast-stream urban life with all its complexities has its own appeal. S. Meno and Alwi asserted that the basic assumption of urban is the place of success. Urban with a series of its characteristics, such as, the prominence of individualistic and fragmented life, the high level of consumerism, high competitiveness in various aspects, the high influence of technology so as to change their lifestyle and behavior. The high pace in urban life, identified with the rapid development of the cyber world, is likened to Piliang as "the running world." The speed of the running world left a significant impact on the urban population. There are some people who are able to follow the fast pace of the running world. However, some find obstacles because of still trying to maintain traditional values that tend to curb their running rate, and some are not at all able to follow the rate [2].

The high technological speed has change the life of urban people. Muthoharoh said that true technology plays a big role in urban life because it is considered to be a solution and effective or efficient for them in the midst of a fast lifestyle and high competitiveness. The influence of cyberspace presence is clearly visible in human life [3]. Piliang says that it is not uncommon for distortions between philosophy, ideology, ethics, and cultural values developed behind the creation of a cyberspace with philosophy, ideology, ethics, and cultural values that are still alive and thriving in society. Religious life becomes less solemn because of physical importance. Piliang said that one of the impacts of the cyberspace is the human tendency to ignore God. The density of urban people activity causes them to spend little time on a person who is considered to possess the absolute truth. In a more extreme context, urban peoples tend to ignore the existence of God. In fact, it is selfdefeating that fosters an absolute individualistic attitude and is in charge of what it desires.

High technology-based civilization seems to neglect the awareness of the existence of the power institution the institution or family. It is not possible if the relationship of kinship or human relationships become tenuous. This allpurpose lifestyle makes humans more familiar to distant environments but keeps them close to nearby environments. The pattern also changes the outlook on the body. The body is 
considered a source of restraints, but the urban man is reluctant to lose the body and parts of his own body [4]. How narcissism and the fear of dying become a culture among urban people, then lead to the growth of facilities and infrastructure that are considered to maintain their existence there.

Urban lifestyles are always being contrasted with rural lifestyle. The urban lifestyle is often used as a model or living standard does not always bring happiness. The binary opposition between the urban lifestyle to the traditional values still held by some societies has led to considerable opposition. Urban peoples who want to leave traditional values and hold firmly the late values, then reap their own losses [5]. The high competitiveness in urban areas has caused tremendous impact. Muthoharoh said that it causes urban people to compete to survive in the crowded and sundry areas in various ways. In extreme conditions, criminality is present, the high level of stress, consumption becomes the need of individual identity.

The urban life with the rapidly-based influence of the digital age has entered so radically within the family environment. The concept of parenting also shifts away. Most of the children's first schools, mothers, many leave home and act as breadwinners. The frequency of meeting with children was reduced drastically. Replacement role is occupied by caregivers or grandmother/grandfather who did not rule out difficulty in understanding the development of contemporary life. Lack of face-to-face frequency and interaction with parents makes children look for their own role models. Not infrequently children find a certain figure that can lead into tragic events that leave tragic footprint in the future. Risman said that lack of interaction with either parent can lead to a deviation of child behavior in the future. Risman gives an example, for example, a boy less close to his father would have no model of identification to be the man his parents expected, how he behaved, behaved, and felt as a man. Meanwhile, girls who are less close to his father, later will tend to easily experience depression and show bad behavior [5,6]. The wrong parenting pattern of parents in extreme conditions can lead to crime.

Jamaludin said that urbanity with all its complexity raises a series of social problems, among them, crime. Kartono conveyed that, in general, crime occurs because of several factors: biological, sociological, economic, mental (religious, reading, daily, film) factors; physical (climatic and other conditions), and personal (age, race, and nationality, alcohol, war). Kartono then convey the cause of juvenile delinquency. It is a failure of the self-control system of instinctive actions; also show a person's inability to control primitive emotions to be sent into useful deeds $[7,8,9]$.

Gender is one element that is also affected in urban life. Gender is a social construct of the different roles of human beings based on sex. It is adaptable so that it can bring into unlimited variants according to the local cultural base. Particularly, gender will be different from similar concepts in other areas. Increased levels of education and mindset achievement as well as work-opportunity imbalances have led to many roles taking within the family. Muthoharoh said that women tend to easily take the role of breadwinner. More men who fall in the domestic world. Zakiah expressed Wood's view of the structure of family relationships in a marriage that identifies the differences of basic roles in a family, especially in the following structures: (1) the complementary structure based on the differences between the couples involved; the dominant one and the other the culprit; (2) The symmetrical structure is based on similarity, e.g. both dominant or penners. Parallel structures are based on several combinations of complementary and symmetrical interactions: for example, dominant males and female custodians, especially in financial terms. However, the roles of both sides are opposed in terms of parenting, and both men and women, are equally dominant when they decide, among them, family vacations $[10,11]$.

The discussion of these urban people connections requires extensive research. However, this paper is just a first step to explore the urban and its complexity in human life. The limitations of the problems standardized in this study are (1) whether urban man cannot stand alone, he always needs connectivity with others, especially when getting into trouble?; (2) whether urban man cannot solve his own problems and he tends to take the issue as an heirloom in life ?; (3) do urban peoples tend to have complex traumatic backgrounds ?; (4) does urban peoples tend to be self-defeating and act on the basis of self-interest ?; and (5) whether urban peoples cannot stand alone with complete sacrifice, but still require traditional values derived from their ancestors.

\section{ReSEARCh Method}

The method used in this paper is qualitative with comparative descriptive analysis. The data were collected in the data contained in the trilogy novel and the two of Indah Hanaco with the theme of urban life. The trilogy novel is titled Heartling (2015), Out of The Blue (2015), and Fixing a Broken Heart (2017). Meanwhile, the other two novel consists of Delicious Marriage (2016) and The Passionate Marriage (2017). The background of taking novel trilogy and the two is for the story to be fully and sustained. The data taken from the fifth novel is a data showing the urban lifestyle and the impact of the lifestyle, both on individuals, as well as in the surrounding environment. The approach used in this paper is cultural studies by summarizing some related concepts, among others, urban, psychology related parenting in the family, gender, and connectivity among urban people $[11,12,13,14,15]$.

\section{RESUlt AND DisCUSSION}

The discussion on "Connections of Urban People on Indah Hanaco" is divided into two sub sections, adapted to the collectivity of data sources, namely trilogy and dilogy. Furthermore, the discussion of the two sub-sections is subdivided into four other sub-sections, respectively, urban, psychology related to parenting in the family, gender, and connectivity among urban people.

\section{A. Heartling, Out of The Blue, and Fixing a Broken Heart}

The trilogy tells of three students who each seems to have traumatic traces that are just as complicated. The three novels tell a traumatic spot in the past, which further identifies the character's attitude. Heartling tells the story of Amara's attitude that is so rigid when see his opponent, his best friend, 
especially the opposite sex. Sophie, at first glance, the story has been presented in Out of The Blue. Meanwhile Fixing a Broken Heart tells Brisha and the problems that arise between the girl and her ex-brutal girlfriend. The discussion of the portrait of urban life in the trilogy is divided into the following four subcategories: urban, psychology related to parenting in the family, gender, and connectivity among urban people.

1) Urban: Hanaco describes the life of the upper middle class. The three main characters, Amara, Sophie, and Brisha grew up in the established family environment. That, seen from the description of Amara and Brisha who get car facility to undergo their deafness. Other figures raised are Ji Hwan, Jamie Keegan, and Austin as lovers of the main characters. The urban lifestyle is very busy, the tendency to live cosmopolitan, especially in the show by the three men's figures, as well as the parents of three female characters. The busyness of the extraordinary figures to require relaxation facilities and infrastructure around their activities, among others, the campus canteen, cafes, restaurants, or vacation to many spots or go abroad (as did Sophie). Familiarity with the world of technology is indicated by the mention of the author of the device used by the characters.

The density of life competitiveness in the urban area is shown by Gitta, a fashion stylist for as actress as well as a female entertainer and a mistress for Dicky, a man entrepreneur who is a Don Juan. Gitta is a reflection of an urban who is willing to do anything to survive. He had a child from his first marriage. She left the child with her mother, that time she was out of town, and she chose to live in a rented house while looking for a job. His unexpected wedding ended briefly. The environment in which he worked led him to promiscuity. His introduction to Dicky, a basketball entrepreneur, brought Debby to a life of high risk. On the one hand, she gets the material that makes him able to travel on the care of the body and face as the main capital in his work. However, the lifestyle requires him to be tied to the urban environment in the cosmopolitan area of Jakarta. When finally, she got a sad event conducted by David Syahrial, a basketball athlete. Apparently, David has a sexual disorder, sadomasochism. This aberrant behavior is suspected as a result of the failure of a person's process of maturity and sexual development or as a result of trauma from past or verbal-physical abuse. Gitta had to bear the consequences by herself. His body is broken and he needs an uncertain time to make a recovery and live a new life. Despite serving other consumers, Gitta remains with Dicky as a regular customer. Dicky also bear some of Gitta's needs.

2) Psychological Related Family Pattern: Urban life with its high competitiveness requires a lot of effort for the population. Not a bit to compete, urban people do things that do not make sense, including something bad. Busyness as high as able to shake the belief in the presence of The Most Powerful is actually able to make them afraid to make a deviation or error. However, the high worldly interests then tend to ignore the fear of the Most Powerful and the punishment that can be imposed from Him. The characters are not depicted to perform ritual activities to worship God.
A solid urban life can be a better place for success. However, it is required physical and mental readiness, especially to face the risk of life. The density of urban people activity schedule is due to the lack of face-to-face intensity of family members or members of the community. Devices are not a guarantee to maintain the quality of relationships between family members or members of the community. In extreme conditions, the device becomes one of the supporters of the emergence of a crime, for example the perpetrator of crime ensnare or threaten the victim.

Lack of face-to-face intensity is causing modern families looking for a substitute role, e.g. being parents. It could be that housekeepers, caregivers, or grandmothers/grandfathers become careers. However, those cannot always meet the ideal criteria, especially with educational background, cultural background, or cultural shock that often cause controversy or even traumatic traces in urban peoples. Marriage becomes fragile because of saturation, as Amara's parents deed have caused a change in behavior patterns, especially, to Amara's mother figure. To escape from the effects, the mother turned her attention into her work as a teacher, both in the teaching environment, the mother spends time teaching in various places as a private teacher. He seemed to forget that he still had two grown children but still needed his attention. After the divorce, the figure of Amara's father moved into the apartment dweller. He seemed to be depicted disappearing. The material facility is still given to Amara and her elder brother, Zeus. This is evidenced by the continuing lectures of both siblings. Nevertheless, traumatic traces of his parents' divorce further lead to Amara's suffering, also not recovered from the trauma of rape, pregnancy, and miscarriage. The cheerful Amara is now become stiff, difficult to trust others, and have difficulty in communicating with the other person, especially the man. Amara always felt that her parents' divorce was due to the shame that had happened to her. Both parents who are already established life cannot withstand the shame of his daughter. Amara lost her faith including her own brother who repeatedly said that their parents' divorce was not a disgrace but because they could not love each other. The dramatic experience which Amara got lead her into the extreme sport. She goes to the gym and do high excessive portions. The pain in his body satisfy her for a moment.

The lack of parental supervision leads to the growth of fragile urban people. Figures of the trilogy are successful or almost successful figures in academics or work. However, it is not so with his mental endurance, especially when they are troubled. Western lifestyle concept that has entered very deeply into the lives of several generations in urban areas, especially in Jakarta, causing vulnerability mental urban people. Problems are considered to be barriers to ideals or even inheritance. The urban man tends to lose his confidence in his interlocutor and chooses to keep quiet, as Amara did after the rape and the miscarriage. Or as experienced by Sophie who spilled the solution of losing a mother figure by cooking. However, it is aimed was not for self-defense, but to realize her subconscious obsession to revive a dead mother's figure who's the rest of her life never knew she had a daughter. Sexual intercourse between Sophie's father and mother led to her pregnancy. Rangga then never know he'll got a child. He never intended to break with 
Dahniar, Sophie's mother. However, Sophie's grandfather closed all Rangga's access to see with Dahniar. The letters from Rangga were never received by Dahniar, while Dahniar sank into the waiting and the acute depression. She spent her lifetime in an asylum. Losing of her mother made Sophie so obsessive to her lover, Austin. Sophie demanded him to be with her. She does not like the Austin profession as a public figure because she had to share her ownership to the fans. However, the obsessiveness began to fade when Rangga suddenly came into her life and the girl got a comfortable spot by Joanna's side, her stepmother. Sophie can be heartfelt when she receives the presence of a Jamie Keegan, a top European actor who love her so much.

Another risky marriage is also shown by Ji Hwan's parents. His father who is Korean and mother of Indonesian both have a high intelligence. However, Ji Hwan sees that their intelligence cannot function properly to solve the problem of the household. The seizure of custody ensued. Ji Hwan was taken by his father and during that time he was forbidden to see his mother. The mother remarried to a man who took her to a half-brother, Marcello. But Ji Hwan had never met him, who then torn her lover, Amara, apart. Marcello wants his parents to reconcile. However, his hopes were dashed when her father decided to marry another woman, Ji Hwan's mother. Ji Hwan hardly recognizes Marcello because he just joined his mother after growing up. Meanwhile, Marcello is drowning in his disappointment, especially his regrets to Amara's disregard for the girl. He dead young.

3) Gender: Gender reflects still overlap. The number of advances in education and mindset allows women to be able to take more space among the public sphere. Nevertheless, in the trilogy, the gender seen still retains traditional values. Female characters, for example, are identic with Cinderella Syndrome. Women's figures are described as being self-sufficient in a particular field, for example, academic or work. However, in their living still have a high level of dependence on the male. Similarly, male characters are also highly dependent on the female. In fact, at an extreme level, male characters tend to be so obsessive with the opposite sex. The position of women in an inferior position has never changed. Male figures placed the female characters as heroes to overcome the emptiness or loneliness they experience.

4) Connectivity Among Urban people: The connectivity is basically a connection of interest. Amara-Sophie-Brisha were interconnected because they have a common background, victims of various violence. The three figures connect with males because all three-need protection and restrain over the difficulties experienced. Meanwhile, the connections made by David Syahrial, Dicky, Marcello, Andaru, and Inez against the "victims" are more based on the object of sexual gratification and their passions.

\section{B. Delicious Marrige and The Passionate Marriage}

Both Delicious Marriges and The Passionate Marriage tells the story of a pure middle-class human life in an urban area. Both featured Milly--a wedding gown designer, and his interaction with Keith--an expatriate cafe entrepreneur, and a row of their colleagues in the Jakarta neighborhood. The discussion of portraits of urban life in both novel is divided into the following four sub-categories: urban, psychology related to parenting in the family, gender, and connectivity among urban people.

1) Urban: One of the urban lifestyles that arise in both novel is the flourishing of gathering places, such as cafes, restaurants, or other food outlets. The background of entrepreneurs in various midwives is very strong. The concept of time is money is so clear. Business owners must pursue increased profit targets and earn a very tight increase in visitor numbers. He must think hard to create new creations, got money from unsold items, got ethical concepts in interacting with clients, and product quality preservation in Delicious Marriage. Milly's character is described as an independent woman who grew from a family with strict rules. She chose the profession as a famous wedding gown designer. Her encounter with Keith reinforced the effort between the two.

However, the ease of public access to their domestic marriage shutter caused an enormous problem. Milly could not finish it without the help of her friends. Even Keith, who felt capable of solving it by himself, was closed access from the barricades of Milly's friends. Rachel, Keith's elder brother, loves Keith obsessively. She never liked the presence of the opposite sex for his sister. In various ways done to separate Keith from his girlfriends and also Milly, even though the woman has then become his wife. Rachel is the owner of an awesome agency that manages some famous stars. She tricked the younger brother to take care of a star and it almost destroyed Keith-Milly's marriage. Moreover, Milly who had had a bad experience with her first marriage, had difficulty solving her own problem with common sense. The Passionate Marriage depicted how public space can easily break the domestic space in marriage. Gwen-Phillips must accept the presence of those surroundings which are still obsessed with having or injuring the wife. The presence of Ben and Elvi, who cannot accept the happiness of Gwen and her twin sister VivitInge, nearly destroyed her second marriage.

2) Psychology Related Patterns of Family Care: Family relationships in a good marriage will certainly make it easier for someone to survive because he will always have a place to share and protect. However, if a relative's relationship has been damaged from the beginning, the next will be getting worse. Gwen has a dark side before her marriage. He was born from a mother who works as a prostitute. Nevertheless, Gwen never regretted the profession that enjoyed so much by her. Gwen is very respectful to her because she is always fight for the needs of his children, even a savings of gold bars for the preparation of children school fees. It's just that both the relationship and her twin sister is quite broken by the older sister of the legal marriage of her mother. Elvi's character often does snickering, both physical and verbal gestures, to Gwen and her twin sister. Moreover, specifically for Gwen, Elvi asked every man who became her boyfriend to do sexual abuse to Gwen. In fact, Elvi took off all the remaining supplies of his mother's gold and sold quietly the house they lived in. 
In addition, elvi follows the mother and becomes as a prostitute and then the unexpectedly get pregnant. The birth of a baby boy did not change her ambition and other her bad habits. Elvi goes back and leaves the baby with Gwen and the twins. Because of panic, Gwen took the baby to Bandung and left him in an orphanage. He was very sorry for his actions but didn't know any idea that time. The darkness made Gwen fight hard as the breadwinner. The severity of the sexual abuse she experienced, not surprising that made Gwen so rigid every time she meets the male.

The relationship of Milly-Adam is destroyed when the social perspective sees a marriage as a reflection of basically consumerism. The baby less marriage Milly-Adam ends up she is unable to give offspring to her husband. Milly was exiled by the Adam's family and she finally choses to divorce. Moreover, the Adam's family welcomed the presence of Kinanti, Milly's own friend, who trap him as the father of the child she was carrying. Milly's and Keith's wedding were inseparable from public interference. Milly-Keith's relationship was inflamed when Rachel unceasingly tried to separate them by bringing the women into their lives.

3) Gender: Despite presenting Rachel as the dominant woman in Keith's life, the novel was unable to erase the traditional gender concept. Since being left on the orphan, Rachel acts as an obsessive mother and older brother to Keith. During that time, Keith was not able to escape from the influence of his sister. In the meantime, Keith and his two best friends in the orphanage, Phillip and Rafe, got good parenting from Tante Rida, the caretaker.

However, Rachel kept control of Keith's life even when he was married to Milly. Milly was publicly humiliated by arranging scenarios with an actress agency whom she manages. On another occasion, Rachel deliberately assigned Keith to accompany Marissa during the interview session. Marissa did actions that hurt Milly so much, especially the session was broadcast in an infotainment show. It was a turning point for Keith to escape the dominant influence of his older sister. He decided to quit the agency and concentrate on the cafes he manages by himself and business plans with his two best friends.

Another dominant woman is Janna, Milly's sister. Janna who tends to a tomboy often becomes a shoulder for her sister. However, Janna is portrayed as a careless woman because she never thought long before taking action. The figure of Janna is limited by the protrusion of her weaknesses, the easy-ignited emotion and her short, careless way of thinking.

Another is described as a formidable woman due to the results of the life school process. They become a breadwinner when the position of men was abandoned and considered unprofitable. However, the toughness faded immediately after their meeting with the figure of their partner. These figures are more placed as heroes and substitutes for the emptiness of the male figure in the life of the woman (especially the father figure). The figure of the woman turned into a Cinderella who so weak without the encouragement of the figure of his partner. On the contrary, the male figure is more likely to see women as inferior to be protected. However, on the other hand, the man's figure experiences Peter-Pan Syndrome. Their high dependence can be seen when they need a void filler of the mother figure.

The role of women in the two is very dominant. However, the position of women is not better than men. In the Passionate Marriage, the position of a prostitute remains a traumatic source for the next generation. It happens when the social eye sees badly to the mother of Gwen and her younger siblings. The insult is very attached to Elvi's self because the proxy of the mother releases the father figure from his side. Especially with the fatherless presence of Gwen and her twin sister, increasingly adding a burden. Losing the figure of the father reflected by using her body so badly and keep the profession of the mother. Elvi seems to represent the instability of women in overcoming the problem (without the help of men) by showing inappropriate behavior, that is, abandoning his siblings and robbing the rest of the mother's property, and doing the terror on Gwen's marriage.

4) Connectivity Among Urban people: The urban people connections depicted in the two are based on the elements of interest. The emerging figures are equally lonely over the loss of the role models. The figures also need each other. However, there is also a figure present who will wreak revenge for the difficulties of the past. He needs the sacrifice to do so regardless of the impact that will arise on the people concerned and the environment around him.

\section{CONCLUSION}

Urban is a region of high complexity with a series of distinctive features, among others, the rhythm of life is very fast, busy, and high competition, and a more diverse cultural background. The high competitiveness leads to unhealthy growth or trigger a person to do anything without prioritizing the consequences he does, both to himself and to others. Not surprisingly, the crime in urban areas is quite high. The four matters expressed in this paper: urban, psychology related to parenting in the family, gender, and connectivity between urban peoples, shows that the study of Hanaco are appropriate in answering these following problems: (1) urban people could not stand alone, but they always needed good connectivity with each other, especially when getting into trouble; (2) urban people could not solve their own problems and they tended to take the issue as an heirloom in life; (3) urban people tended to have complex traumatic backgrounds; (4) urban people tended to be self-defeating and self-interest; and (5) urban people could not stand alone with complete urban values, but still required traditional values which was derived from their ancestors.

\section{REFERENCES}

[1] S. Meno and M. Alwi, Antropologi Perkotaan. Jakarta: Yayasan Obor Indonesia, 1992.

[2] A.Y. Piliang, Dunia yang Berlari: Mencari Tuhan-Tuhan Digital, 2004. pp. 22.

[3] A. Muthoharoh, Budaya Urban, http://aliyahmuthoharohfib09.web.unair.ac.id, 2013.

[4] A.Y. Piliang, Dunia yang Berlari: Mencari Tuhan-Tuhan Digital, 2004. pp.22. 
[5] E. Risman, Elly dalam Safiera, Alyssa, 7 Tips Pengasuhan Anak di Era Digital dari Psikolog Elly Risman, https://m.detik.com/wolipop/, 2016.

[6] Risman, Elly dalam Setiawan, Iwan, Ed., Para Orang tua Wajib Tahu, Ternyata 7 Pola Asuh ini Bisa Jadi Penyebab Anak Menjadi LGBT, 2016

[7] A.N. Jamaludin, Sosiologi Perkotaan; Memahami Masyarakat Kota dan Problematikanya. Bandung: Pustaka Setia, 2015.

[8] K. Kartono, Patologi Sosial 2 Kenakalan Remaja, Jakarta: Grafindo Persada, pp. 142-143

[9] A. Muthoharoh, Budaya Urban, http://aliyahmuthoharohfib09.web.unair.ac.id, 2013.
[10] K. Zakiah, "Hubungan dalam Komunikasi Diadik Suami-Istri: Perpektif Sosiologi Suami-Istri”, Jurnal Mediator, vol. 3, no. 2, 2002, pp. 295304.

[11] I. Hanaco, Heartling, Jakarta: Gramedia Pustaka Utama, 2015.

[12] I. Hanaco, Out of The Blue, Jakarta: Gramedia Pustaka Utama, 2015.

[13] I. Hanaco, Fixing a Broken Heart, Jakarta: Gramedia Pustaka Utama, 2017.

[14] I. Hanaco, Delicious Marriage, Jakarta: Gramedia Pustaka Utama, 2016.

[15] I. Hanaco, The Passionate Marriage, Jakarta: Gramedia Pustaka Utama, 2017. 